\title{
PENGARUH STRATEGI BELAJAR AKTIF SORTIR KARTU TERHADAP KEMAMPUAN PEMECAHAN MASALAH MATEMATIS
}

\author{
Rilla Gina Gunawan ${ }^{1}$, Aan Putra ${ }^{2}$ \\ ${ }^{1,2}$ Institut Agama Islam Negeri Kerinci, Jalan Kapten Muradi Kota Sungai Penuh, Jambi. 37112 - Indonesia \\ Rilla_rozika@yahoo.com
}

\begin{abstract}
The aim of this research is finding students' mathematical problem solving skills based on high, medium and low initial knowledge. This research is a quasi-experimental study. The research sample used students in VIIIA and students in VIIIB SMPN 1 Kerinci that selected using random sampling techniques. The research data were processed using the t-test and the Mann Whitney test to comparing students' problem solving skills that using active learning strategy sorting cards and problem solving skills of students that using ordinary learning. The result of data analysis showed that the mathematical problem solving skill of students with high, medium and low initial knowledge was better than the mathematical problem solving skill of students with the same initial knowledge that used ordinary learning.
\end{abstract}

Keywords: sort cards strategy, active learning strategy, mathematical problem solving skills

Abstrak

Penelitian ini bertujuan untuk mengetahui perbandingan kemampuan pemecahan masalah matematika siswa berdasarkan pengetahuan awal tinggi, sedang dan rendah. Penelitian ini merupakan penelitian eksperimental semu. Sampel penelitian yang digunakan adalah siswa di VIIIA dan siswa di VIIIB SMPN 1 Kerinci yang dipilih menggunakan teknik random sampling. Data hasil penelitian diolah menggunakan uji t dan uji Mann Whitney dengan tujuan membandingkan kemampuan pemecahan masalah siswa yang menggunakan strategi belajar aktif sortir kartu dan kemampuan pemecahan masalah siswa yang menggunakan pembelajaran biasa. Hasil penelitian menunjukkan bahwa kemampuan pemecahan masalah matematika siswa dengan pengetahuan awal tinggi, sedang dan rendah lebih baik daripada kemampuan pemecahan masalah matematika siswa dengan kemampuan awal yang sama yang menggunakan pembelajaran biasa.

Kata kunci: strategi belajar aktif sortir kartu, kemampuan pemecahan masalah matematis

Matematika merupakan suatu pengetahuan yang dapat melatih cara berpikir menjadi logis, kritis dan kreatif. Matematika dapat masuk dalam seluruh segi kehidupan manusia, dari yang paling sederhana sampai pada yang paling kompleks. Dalam keseharian, banyak hal yang ditemukan yang berhubungan dengan matematika yang terpakai dalam kehidupan. Untuk itu, pembelajaran matematika sangat diperlukan di sekolah-sekolah. Hal ini tentu saja bertujuan untuk membantu siswa memecahkan masalah yang dihadapinya dalam kehidupan sehari-hari (Wulansari, Putra, Rusliah, \& Habibi, 2019).

Sebagaimana yang tercantum dalam Kurikulum Tingkat Satuan Pendidikan (KTSP) bahwa mate-matika merupakan ilmu universal yang mendasari perkembangan teknologi modern, mempunyai peranan penting dalam berbagai disiplin dan mengembangkan daya pikir manusia. Perkembangan pesat di bidang teknologi informasi dan komunikasi dewasa ini dilandasi oleh perkembangan matematika. Untuk dapat menciptakan teknologi di masa depan diperlukan penguasaan matematika yang kuat sejak dini. Oleh karena itu, matematika dipelajari di semua jenjang pendidikan yaitu mulai dari tingkat SD, SMP, SMA / SMK sampai Perguruan Tinggi.

Berkaitan dengan pembelajaran matematika, Sumarmo (2000) mengatakan bahwa dalam belajar matematika siswa dituntut untuk memiliki kemampuan: penalaran, pemecahan masalah, komunikasi dan koneksi matematis. Dalam pembelajaran matematika hendaknya mengutamakan pada pengembangan daya matematik siswa yang meliputi: kemampuan menggali, menyusun konjektur dan 
Pengaruh Strategi Belajar Aktif Sortir Kartu Terhadap Kemampuan Pemecahan Masalah Matematis, Rilla Gina Gunawan, Aan Putra

menalar secara logik, menyelesaikan masalah yang tidak rutin, berkomunikasi secara matematika dan mengaitkan ide matematika dengan kegiatan intelektual lainnya.

Kemampuan pemecahan masalah merupakan kemampuan yang esensial untuk dikembangkan pada siswa sekolah menengah. Pentingnya kemampuan matematis diatas termuat dalam tujuan KTSP (Depdiknas, 2006) melalui Permendiknas No 22 tentang Standar Isi telah dinyatakan bahwa tujuan pelajaran matematika di SD/MI, SMP/MTs, SMA/MA, dan SMK/MAK adalah agar peserta didik: (1) Memahami pemahaman konsep matematika, menjelaskan keterkaitan antar konsep dan mengaplikasikan konsep atau algoritma, secara luwes, akurat, efisien, dan tepat dalam pemecahan masalah. (2) Mengkomu-nikasikan gagasan dengan simbol, tabel, diagram, atau media lain untuk memperjelas keadaan atau masalah (3) Memiliki sikap menghargai kegu-naan matematika dalam kehidupan, yaitu memiliki rasa ingin tahu, perhatian, dan minat dalam mem-pelajari matematika, serta sikap ulet dan percaya diri dalam pemecahan masalah.

Berdasarkan tujuan pelajaran matematika seharusnya matematika merupakan mata pelajaran yang memiliki daya tarik dan tantangan tersendiri bagi siswa sehingga meningkatkan motivasi siswa untuk mempelajari matematika. Guru hendaknya memilih dan menggunakan model, strategi, pendekatan, metode, dan teknik yang banyak melibatkan siswa aktif dalam belajar, baik secara mental, fisik maupun sosial.

Namun faktanya di lapangan, hasil belajar matematika siswa belum begitu menggembirakan. Berdasarkan observasi dan wawancara dengan guru matematika kelas VIII SMPN 1 Kerinci, diketahui bahwa masih rendahnya pemahaman siswa terhadap pemecahan masalah matematis. Siswa hanya mampu menyelesaikan soal matematika yang sama dengan contoh soal. Metode yang digunakan guru dalam proses pembelajaran belum bervariasi. Kegiatan guru di dalam kelas hanya menjelaskan materi, contoh soal dan latihan. Padahal, hakikat pembelajaran bukanlah kegiatan memindahkan pengetahuan dari guru kepada siswa, melainkan suatu kegiatan yang memungkinkan siswa membangun sendiri pengetahuannya.

Selama ini, telah banyak usaha yang dilakukan guru untuk mengatasi masalah yang ada, diantaranya dengan memberikan penjelasan materi beserta contoh-contoh soal dan memberikan latihan yang harus dikerjakan siswa secara mandiri atau berkelompok. Akan tetapi, usaha tersebut juga belum membuahkan hasil yang optimal karena masih terdapat kendala-kendala yang dihadapi dalam proses belajar. Untuk itu, permasalahan ini harus diatasi agar proses pembelajaran dapat berjalan dengan baik, maka diupayakan strategi pembelajaran yang bervariasi. Salah satu cara untuk mengatasi hal tersebut adalah dengan menggunakan Strategi Belajar Aktif Sortir Kartu. Strategi Belajar Aktif Sortir Kartu adalah suatu strategi pembelajaran yang mengajak siswa untuk belajar aktif dan bertujuan agar siswa mempunyai jiwa kemandirian dalam belajar serta menumbuhkan daya kreatifitas sehingga mampu membuat inovasi-inovasi (Zaini, 2008).

Penerapan Strategi Belajar Aktif Sortir Kartu telah dicobakan oleh peneliti terdahulu untuk meningkatkan prestasi belajar siswa (Witari, Rery \& Haryati, 2017), pemahaman konsep matematis 
(Fadhillah, 2017), kemampuan berbicara (Stofiana, 2017) dan hasil belajar siswa secara umum (Kusyono, 2010; Safitri, 2017). Langkah-langkah dalam Strategi Belajar Aktif Sortir Kartu tersebut berbeda dengan pembelajaran konvensional. Pembelajaran konvensional adalah cara menyampaikan informasi atau keterangan tentang suatu pokok permasalahan secara lisan, dimana kegiatan berpusat pada guru, siswa hanya menerima informasi dengan cara mendengarkan dan mencatat. Menurut Depdiknas (2006) menyatakan bahwa pembelajaran konvensional mempunyai ciri-ciri sebagai berikut: a). Pembelajaran tidak memperhatikan pengalaman siswa, b). Pembelajaran abstrak dan teoritis dan c). Penilaiannya hanya ditentukan oleh tes bukan pada penilaian proses belajar.

Pembelajaran konvensional memiliki perbedaan dengan Stategi Belajar Aktif Sortir kartu. Perbedaan yang paling utama terletak pada tahap penyajian masalah. Dalam Stategi Belajar Aktif Sortir kartu masalah disajikan pada awal pembelajaran yang mendorong siswa untuk menemukan konsep dengan memberikan kartu yang berisikan masalah-masalah yang harus dibahas oleh siswa. Sedangkan pada proses pembelajaran konvensional, masalah diberikan pada akhir pembelajaran setelah guru menyampaikan materi pembelajaran. Oleh sebab itu Stategi Belajar Aktif Sortir kartu dipilih sebagai salah satu startegi pembelajaran yang dapat meningkatkan kemampuan pemecahan masalah matematis siswa. Perbedaan Stategi Belajar Aktif Sortir kartu dan pembelajaran konvensional dapat dilihat pada Tabel 1.

\section{Tabel 1.}

Perbedaan Stategi Belajar Aktif Sortir kartu dengan Pembelajaran Konvensional

\begin{tabular}{|c|c|c|}
\hline No & Strategi Belajar Aktif Sortir Kartu & Pembelajaran Kon \\
\hline 1 & $\begin{array}{l}\text { Siswa secara aktif terlibat dalam proses } \\
\text { pembelajaran untuk mencari informasi }\end{array}$ & $\begin{array}{l}\text { Siswa adalah penerima informasi secara } \\
\text { pasif }\end{array}$ \\
\hline & Siswa membangun pengetahuan sendiri & $\begin{array}{l}\text { Pengetahuan disampaikan dari guru ke } \\
\text { siswa }\end{array}$ \\
\hline 2 & $\begin{array}{l}\text { Siswa belajar secara berkelompok dalam bentuk } \\
\text { diskusi untuk menyelesaikan soal-soal yang ada } \\
\text { pada kartu, dan ada pula kegiatan belajar yang } \\
\text { dilakukan secara individual }\end{array}$ & Siswa belajar secara individual \\
\hline 3 & $\begin{array}{l}\text { Bahan pelajaran disajikan dengan metode yang } \\
\text { bervariasi. }\end{array}$ & $\begin{array}{l}\text { Bahan pelajaran kebanyakan disajikan } \\
\text { dalam bentuk metode ceramah }\end{array}$ \\
\hline 4 & $\begin{array}{l}\text { Bahasa diajarkan dengan pendekatan } \\
\text { komunikatif, yakni siswa diajak menggunakan } \\
\text { bahasa dalam konteks yang nyata }\end{array}$ & $\begin{array}{l}\text { Bahasa diajarkan dengan pendekatan } \\
\text { struktural: rumus diterangkan sampai } \\
\text { faham, kemudian dilatihkan }\end{array}$ \\
\hline 5 & $\begin{array}{l}\text { Siswa menggunakan kemampuan matematis, } \\
\text { terlibat penuh dalam upaya terjadinya proses } \\
\text { pembelajaran yang efektif }\end{array}$ & $\begin{array}{l}\text { Siswa secara pasif menerima rumus } \\
\text { (mendengarkan, mencatat, menghafal) } \\
\text { tanpa memberikan kontribusi ide dalam } \\
\text { proses pembelajaran }\end{array}$ \\
\hline 6 & $\begin{array}{l}\text { Siswa ikut bertanggungjawab dalam penentu } \\
\text { jalannya proses pembelajaran }\end{array}$ & $\begin{array}{l}\text { Guru adalah penentu jalannya proses } \\
\text { pembelajaran }\end{array}$ \\
\hline 8 & $\begin{array}{l}\text { Hasil belajar diukur dengan berbagai cara: } \\
\text { proses, penampilan, tes dan lain-lain }\end{array}$ & Hasil belajar diukur hanya dengan tes \\
\hline 9 & $\begin{array}{l}\text { Siswa ikut memberikan informasi / ide-ide atau } \\
\text { pengalaman dalam kegiatan pembelajaran }\end{array}$ & Inforn \\
\hline
\end{tabular}


Pengaruh Strategi Belajar Aktif Sortir Kartu Terhadap Kemampuan Pemecahan Masalah Matematis, Rilla Gina Gunawan, Aan Putra

\begin{tabular}{|c|l|l|}
\hline 10 & $\begin{array}{l}\text { Adanya keberanian siswa mengajukan } \\
\text { pendapatnya melalui pernyataan atau } \\
\text { pertanyaan gagasan }\end{array}$ & $\begin{array}{l}\text { Siswa kurang berpartisipasi dalam } \\
\text { mengajukkan pertanyaan }\end{array}$ \\
\hline 11 & $\begin{array}{l}\text { Peran guru sebagai pendorong dan fasilitator } \\
\text { dalam pembelajaran }\end{array}$ & $\begin{array}{l}\text { Peran guru sebagai pemberi informasi dan } \\
\text { penilai }\end{array}$ \\
\hline
\end{tabular}

Kemampuan pemecahan masalah matematis merupakan kemampuan dalam matematika yang harus dikuasai siswa. Kemampuan pemecahan masalah matematis adalah suatu tindakan untuk menyelesaikan masalah atau proses yang menggunakan kekuatan dan manfaat matematika dalam menyelesaikan masalah (Ahmad, Deswita, Ningsih \& Syafriadi, 2017), yang juga merupakan metode penemuan solusi melalui tahap-tahap pemecahan masalah. Menurut pendapat beberapa ahli, Suherman (2002), menyatakan "Belajar pemecahan masalah adalah tipe belajar yang paling tinggi karena lebih kompleks dari pembentukan aturan". Oleh karena itu, kemampuan memecahkan masalah memerlukan proses berfikir yang terarah untuk menghasilkan gagasan, ide, atau mengembangkan kemungkinan menyelesaikan masalah-masalah yang dihadapi (Meditamar, Gunawan, Oktafia \& Nurmailis, 2017). Polya (dalam Suherman, 2002) juga berpendapat bahwa solusi soal pemecahan masalah adalah memahami masalah, merencanakan penyelesaian, menyelesaikan masalah yang sesuai rencana, dan melakukan pengecekan kembali terhadap semua langkah yang telah dikerjakan. Hal tersebut diperkuat oleh Dokumen Peraturan Dirjen Dikdasmen No. 506/C/PP/2004 (Depdiknas, 2006) yang menyatakan bahwa pemecahan masalah merupakan kompetensi strategi yang ditunjukkan siswa dalam memahami, memilih pendekatan dan strategi pemecahan masalah, dan menyelesaikan model untuk menyelesaikan masalah indikator yang digunakan untuk menilai kemampuan pemecahan masalah matematis siswa dalam penelitian ini adalah (1) mengidentifikasikan unsur-unsur yang diketahui dari suatu permasalahan, (2) membuat perumusan dari permasalahan, dan (3) menentukan strategi yang tepat dalam menyelesaikan permasalahan.

Pada proses pembelajaran, faktor lain yang menentukan serta mempengaruhi keberhasilan belajar matematika siswa adalah kemampuan awal (Ulandari, Putri, Ningsih \& Putra, 2019). Kemampuan awal adalah kemampuan yang dimiliki siswa sebagai dasar sebelum mereka mengikuti pembelajaran yang akan diberikan. Kemampuan awal ini menggambarkan kesiapan siswa dalam menerima pelajaran yang akan berlangsung. Kemampuan ini berupa pemahaman siswa terhadap materi prasyarat atau materi awal yang harus mereka kuasai sebelum masuk kepada materi baru. Sebelum memulai pembelajaran guru perlu mengetahui kemampuan awal siswa, karena dapat diketahui apakah siswa tersebut sudah memiliki pengetahuan prasyarat untuk mengikuti pembelajaran. Apabila materi awal sudah dipahami dengan baik, maka dapat diduga bahwa siswa akan mudah memahami materi selanjutnya.

Tujuan penelitian ini adalah untuk mengetahui apakah (1) Kemampuan pemecahan masalah matematis siswa yang diajar dengan Strategi Belajar Aktif Sortir Kartu lebih baik dari pada kemampuan pemecahan masalah matematis siswa yang diajar dengan pembelajaran konvensional. (2) Kemampuan 
pemecahan masalah matematis siswa berkemampuan awal tinggi, sedang dan rendah yang diajar dengan Strategi Belajar Aktif Sortir Kartu lebih baik dari pada siswa berkemampuan awal tinggi yang diajar dengan pembelajaran konvensional.

\section{METODE}

Penelitian ini merupakan penelitian eksperimen semu (quasi experiment) dengan rancangan penelitian Randomized Control Group Only Design. Variabel-variabelnya terdiri dari (1) variabel bebas yaitu pembelajaran dengan Strategi Belajar Aktif Sortir Kartu (2) variabel terikat yaitu kemampuan pemecahan masalah, dan (3) variabel moderator yaitu pengetahuan awal siswa. Populasi pada penelitian ini adalah seluruh siswa kelas VIII SMP Negeri 1 Kerinci. Teknik pengambilan sampel adalah Random Sampling. Sampel yang terpilih adalah siswa kelas VIIIA sebanyak 29 orang siswa sebagai kelas eksperimen dan siswa kelas VIIIB sebanyak 32 orang siswa sebagai kelas kontrol. Instrumen yang digunakan dalam pengumpulan data adalah tes kemampuan awal dan tes akhir untuk melihat kemampuan pemecahan masalah. Tes kemampuan awal dan tes akhir yang diberikan kepada siswa adalah soal yang sama. Sebelum tes kemampuan awal dan tes akhir diberikan pada kelas sampel, terlebih dahulu dilakukan uji coba terhadap kedua tes tersebut. Untuk uji coba tes kemampuan awal dilakukan pada kelas VIIID dan uji coba tes akhir dilakukan pada kelas IX SMP Negeri 1 Kerinci. Teknik analisis data yang digunakan adalah melakukan uji normalitas, uji homogenitas, dan uji hipotesis terhadap skor kemampuan pemecahan masalah matematis. Pengujian hipotesis terhadap kemampuan pemecahan masalah matematis dilakukan dengan uji t jika datanya normal dan homogen selanjutnya jika datanya tidak normal dilakukan dengan uji Mann Whitney (Statistik U).

\section{HASIL}

Kemampuan Awal

Tes kemampuan awal merupakan tes yang berguna untuk mengetahui kemampuan prasyarat dalam mempelajari materi atau untuk mengukur kemampuan awal siswa. Tes ini diberikan kepada siswa kelas eksperimen dan kelas kontrol pada awal pembelajaran. Setelah tes ini diberikan kepada siswa, selanjutnya hasil tes kemampuan awal tersebut dianalisis untuk mengelompokkan siswa berdasarkan kemampuan awalnya, yaitu siswa berkemampuan awal tinggi, sedang, dan rendah. Dari hasil analisis diperoleh bahwa siswa yang berkemampuan awal tinggi adalah siswa yang memiliki nilai $\geq 72,97$, untuk siswa yang ber-kemampuan awal sedang adalah siswa yang memiliki nilai antara 19,68 dan 72,97, dan untuk siswa yang berkemampuan awal rendah adalah siswa yang memiliki nilai $\leq 19,68$.

Berdasarkan kriteria tersebut, siswa kelas eksperimen dan kelas kontrol dikelompokkan berdasarkan kemampuan awalnya. Dari 29 orang siswa kelas eksperimen terdapat 6 siswa yang berkemampuan awal tinggi, 17 orang siswa yang ber-kemampuan awal sedang, dan 6 orang siswa yang berkemampuan awal rendah. Dari 32 orang siswa kelas kontrol terdapat 6 siswa yang berkemampuan awal tinggi, 17 orang siswa berkemampuan awal sedang, dan 9 orang siswa yang berkemam-puan awal rendah. 
Pengaruh Strategi Belajar Aktif Sortir Kartu Terhadap Kemampuan Pemecahan Masalah Matematis, Rilla Gina Gunawan, Aan Putra

\section{Kemampuan Pemecahan Masalah Matematis}

Data kemampuan pemecahan masalah matematis siswa diperoleh melalui tes akhir. Tes akhir diberikan kepada kedua kelas sampel dengan memperhatikan kemampuan awal siswa. Data tes akhir diberi skor menggunakan rubrik penskoran kemampauan pemecahan masalah yang dikembangkan oleh Fauzan (2011) untuk melihat kemampuan pemecahan masalah matematis siswa pada kedua kelas sampel.. Hasil analisis tes akhir kemampuan pemecahan masalah ma-tematis dapat dilihat pada Tabel 2.

Tabel 2.

Hasil Analisis Data Tes Kemampuan Pemecahan Masalah Matematis

\begin{tabular}{|c|c|c|c|c|c|c|c|}
\hline \multicolumn{8}{|c|}{ Kemampuan Pemecahan Masalah Matematis } \\
\hline Kelas & Kemampuan & $\mathbf{N}$ & $\overline{\boldsymbol{x}}$ & $\boldsymbol{S}$ & $\boldsymbol{S}^{\mathbf{2}}$ & Xmin & Xmax \\
\hline \multirow{4}{*}{ Eksperimen } & Tinggi & 6 & 9,33 & 1,633 & 2,666 & 6 & 12 \\
\cline { 2 - 8 } & Sedang & 17 & 7 & 1,414 & 1,999 & 4 & 10 \\
\cline { 2 - 8 } & Rendah & 6 & 4,17 & 2,401 & 5,7648 & 2 & 7 \\
\cline { 2 - 8 } & Total & 29 & 6.90 & 2.350 & 5,5225 & 2 & 12 \\
\hline \multirow{4}{*}{ Kontrol } & Tinggi & 6 & 6.67 & 1,633 & 2,666 & 4 & 8 \\
\cline { 2 - 8 } & Sedang & 17 & 3,88 & 2,446 & 5,98 & 0 & 10 \\
\cline { 2 - 8 } & Rendah & 9 & 1,33 & 1,803 & 3,2508 & 0 & 6 \\
\cline { 2 - 8 } & Total & 32 & 3,69 & 2.776 & 7,7061 & 0 & 10 \\
\hline
\end{tabular}

Pada Tabel 2 terlihat bahwa rata-rata skor kemampuan pemecahan masalah matematis siswa secara total dan sedang kelas eksperimen lebih tinggi dibandingkan rata-rata skor kelas kontrol. Dengan demikian dapat dikatakan bahwa kemampuan pemecahan masalah matematis siswa kelas eksperimen pada materi garis sing-gung lingkaran lebih baik dari pada kelas kontrol. Variansi skor tes akhir kelas eksperimen lebih rendah dibandingkan dengan kelas kontrol artinya kemampuan akademik siswa kelas kontrol lebih beragam dari pada kelas eksperimen. Selain itu, simpangan baku skor tes akhir pada kelas eksperimen lebih rendah dari pada kelas kontrol. Dengan kata lain, jarak skor tes akhir siswa kelas eksperimen dengan rata-rata kelasnya tidak begitu jauh jika dibandingkan dengan kelas kontrol yang memiliki simpangan baku lebih besar.

Pada kemampuan pemecahan masalah matematis siswa yang berkemampuan awal tinggi terlihat bahwa rata-rata skor kelas eksperimen lebih tinggi dibandingkan rata-rata skor kelas kontrol. Dengan demikian dapat dikatakan bahwa kemampuan Pemecahan masalah matematis siswa yang berkemampuan awal tinggi kelas eksperimen pada materi garis singgung lingkaran lebih baik dari pada kelas kontrol. Variansi skor tes akhir kelas eksperimen sama dengan kelas kontrol artinya kemampuan akademik siswa kelas kontrol sama dengan kelas eksperimen. Selain itu, simpangan baku skor tes akhir pada kelas eksperimen juga sama dengan kelas kontrol. Dengan kata lain, jarak skor tes akhir siswa kelas eksperimen dengan rata-rata kelasnya tidak begitu jauh dengan dengan kelas kontrol.

Pada kemampuan pemecahan masalah matematis siswa yang berkemampuan awal rendah terlihat bahwa rata-rata skor kelas eksperimen lebih tinggi dibandingkan rata-rata skor kelas kontrol. Dengan demikian dapat dikatakan bahwa kemampuan Pemecahan masalah matematis siswa yang 
berkemampuan awal sedang kelas eksperimen pada materi garis singgung lingkaran lebih baik dari pada kelas kontrol. Variansi skor tes akhir kelas eksperimen lebih tinggi dibandingkan dengan kelas kontrol artinya kemampuan akademik siswa kelas eksperimen lebih beragam dari pada kelas kelas kontrol. Selain itu, simpangan baku skor tes akhir pada kelas eksperimen lebih tinggi dari pada kelas kontrol. Dengan kata lain, jarak skor tes akhir siswa kelas eksperimen dengan rata-rata kelasnya lebih jauh jika dibandingkan dengan kelas kontrol yang memiliki simpangan baku lebih kecil.

Rata-rata skor kemampuan pemecahan masalah matematis siswa kelas eksperimen yang diajar dengan Strategi Belajar Aktif Sortir Kartu lebih tinggi dari pada kelas kontrol yang diajar dengan pembelajaran konvensional. Dari segi kemampuan awal, peningkatan kemampuan peme-cahan masalah matematis siswa berkemampuan awal tinggi, sedang, dan rendah juga lebih tinggi dari pada kelas kontrol. Hal ini terjadi karena dengan Strategi Belajar Aktif Sortir Kartu siswa dibiasakan untuk menyelesaikan masalah yang ada pada Kartu yang diberikan oleh guru dan menemukan sendiri konsep tentang materi yang sedang mereka pelajari sehingga kemampuan peme-cahan masalah matematis siswa pada setiap pertemuan dapat dilatih. Dan berbeda dengan kelas kontrol, dalam pembelajaran tidak diawali dengan masalah yang dapat melatih kemampuan pemecahan masalah matematis siswa. Siswa hanya menerima konsep yang diberikan guru dan masalah diberikan pada akhir pembelajaran sebagai contoh soal dan latihan.

Kemampuan pemecahan ma-salah matematis yang berhasil ditingkatkan oleh Strategi Belajar Aktif Sortir Kartu terjadi karena Strategi Belajar Aktif Sortir Kartu memiliki beberapa keunggulan, seperti yang diungkapkan oleh Silberman (2006) adalah sebagai berikut: (1) Siswa lebih aktif dalam kegiatan pembelajaran karena melibatkan siswa untuk saling berbagi pengetahuan sesama siswa yang satu dengan yang lainnya. (2) Siswa dapat mengingat materi pelajaran yang disampaikan dan dapat meningkatkan pemahaman terhadap konsep dengan saling berbagi atau mengajarkan antara sesama siswa. (3) Siswa berani mengungkapkan pendapat di depan teman-temannya dan menciptakan suasana belajar yang demokratis. (4) Melatih siswa belajar secara kelompok dan kerjasama didalam tim.

Suasana pembelajaran dengan Strategi Belajar Aktif Sortir Kartu terlihat bahwa siswa lebih aktif dan dan pembelajaran jadi menyenangkan, walaupun diawal pembelajaran siswa belum terbiasa dengan pembelajaran yang digunakan, sebagian besar siswa mengaku belum terbiasa dengan pembelajaran yang memerlukan dan menuntut keaktifan siswa. Hal ini disebabkan karena siswa terbiasa dengan pembelajaran konvensinal dimana peran guru lebih mendominasi kelas. Namun hal demikian tidak lagi terjadi pada pertemuan berikutnya. Pada pertemuan berikutnya siswa sudah mulai terbiasa dengan Pembelajaran dengan Strategi Belajar Aktif Sortir Kartu dan siswa terlihat lebih antusias dan bersemangat dalam mengikuti pembelajaran.

Berdasarkan hasil analisis data kemampuan pemecahan masalah matematis terhadap pengujian hipotesis statistik dengan uji t dan uji Mann Whitney (Statistik U) pada taraf signifikansi $(0,05)$, ternyata kemampuan pemecahan masalah matematis siswa baik secara keseluruhan maupun dari segi kemampuan awal mempunyai nilai Sig. lebih kecil dari taraf signifikansi $(0,05)$. Dengan demikian dapat 
Pengaruh Strategi Belajar Aktif Sortir Kartu Terhadap Kemampuan Pemecahan Masalah Matematis, Rilla Gina Gunawan, Aan Putra

disimpulkan bahwa kemampuan pemecahan masalah matematis siswa yang diajar dengan Strategi Belajar Aktif Sortir Kartu lebih baik daripada siswa yang diajar dengan pembelajaran konvensional.

\section{KESIMPULAN}

Berdasarkan hasil analisis data dan pembahasan, diperoleh kesimpulan bahwa (1) Kemampuan pemecahan masalah matematis siswa yang mendapat pembelajaran dengan Strategi Belajar Aktif Sortir Kartu lebih baik dari pada kemampuan pemecahan masalah matematis siswa yang mendapat pembelajaran dengan pembelajaran konvensional pada siswa kelas VIII SMPN 1 Kerinci; (2) Kemampuan pemecahan masalah matematis siswa berkemampuan awal tinggi, sedang, dan rendah yang mendapat pembelajaran dengan Strategi Belajar Aktif Sortir Kartu lebih baik dari pada siswa berkemampuan awal tinggi, sedang, dan rendah yang mendapat pembelajaran dengan pem-belajaran konvensional pada siswa kelas VIII SMPN 1 Kerinci.

Saran yang dapat dikemukakan setelah dilakukan penelitian ini, yaitu kepada guru matematika SMP Negeri 1 Kerinci diharapkan dapat menerapkan Strategi Belajar Aktif Sortir Kartu dalam proses pembelajaran karena terbukti dapat meningkatkan kemampuan pemecahan masalah matematis siswa terhadap matematika. Untuk peneliti lain yang ingin melakukan penelitian yang sama agar dapat membagi waktu sehingga semua komponen Strategi Belajar Aktif Sortir Kartu terlaksana dengan baik dan perlu penelitian lebih lanjut mengenai implementasi pembelajaran dengan Strategi Belajar Aktif Sortir Kartu ini pada pokok bahasan lain.

\section{DAFTAR PUSTAKA}

Ahmad, B., Deswita, R., Ningsih, F \& Syafriadi (2017). Pengaruh Model Pembelajaran CORE dengan Pendekatan Scientific terhadap Kemampuan Pemecahan Masalah Matematis dan Mathematical Habits Of Mind Mahasiswa Matematika. Tarbawi: Jurnal Ilmu Pendidikan, 13(2), 33-42

Depdiknas. (2006). Permendiknas No. 22 tentang SI dan SKL. Jakarta: Sinar Grafika.

Fadhillah, A. P. (2017). Pengaruh Penerapan Strategi Pembelajaran Aktif Tipe Card Sort Terhadap Pemahaman Konsep Matematis Siswa Sekolah Menengah Pertama Negeri 10 Pekanbaru Ditinjau Dari Kemampuan Awal (Doctoral dissertation, Universitas Islam Negeri Sultan Syarif Kasim Riau).

Fauzan, A. (2011). Modul Evaluasi Pembelajaran Matematika: Pemecahan Masalah Matematika. Padang: Universitas Negeri Padang Press.

Kusyono, A. (2010). Penerapan Strategi Pembelajaran Card Sort Dengan Penggunaan Macro Media Flash Untuk Meningkatkan Hasil Belajar Siswa Pada Pokok Bahasan Saling Ketergantungan Dalam Ekosistem Pada Siswa Kelas VII SMPN 3 Polanharjo Klaten TA 2009/2010 (Doctoral dissertation, Universitas Muhammadiyah Surakarta). 
Meditamar, M. O., Gunawan, R. G., Oktafia, M., \& Nurmailis, N. (2017). Pengaruh Strategi Belajar Murder dengan Setting Belajar Kelompok Terhadap Kemampuan Pemecahan Masalah Matematika Siswa SMP Negeri 1 Kerinci. Tarbawi: Jurnal Ilmu Pendidikan, 13(1), 11-21.

National Council of Teachers of Mathematics (Ed.).(2000). Principles and Standards for School Mathematics (Vol. 1). Reston, VA: NCTM.

Safitri, M. (2017). Pengaruh Strategi Pembelajaran Aktif Tipe Card Sort Terhadap Hasil Belajar IPS Siswa Kelas IV SD Negeri 10 Metro Timur.

Stofiana, T. (2017). Peningkatan Kemampuan Berbicara Pada Pembelajaran Bercerita Pengalaman Meggunakan Media Sortir Kartu (Sort Card) Pada Siswa Kelas X-3 SMA Negeri 2 Lasalimu Selatan. Sang Pencerah: Jurnal Ilmiah Universitas Muhammadiyah Buton, 3(2), 79-86.

Suherman, E. (2002). Strategi Pembelajaran Matematika Kontemporer. Bandung: UPI.

Sumarmo, U. (2000). Pengukuran Evaluasi dalam Pendidikan. Bandung: UPI.

Ulandari, N., Putri, R., Ningsih, F., \& Putra, A. (2019). Efektivitas Model Pembelajaran Inquiry terhadap Kemampuan Berpikir Kreatif Siswa pada Materi Teorema Pythagoras. Jurnal Cendekia: Jurnal Pendidikan Matematika, 3(2), 227-237.

Witari, M., Rery, R. U., \& Haryati, S. (2017). Penerapan Strategi Pembelajaran Aktif Tipe Card Sort (Kartu Sortir) untuk Meningkatkan Prestasi Belajar Siswa pada Pokok Bahasan Hidrokarbon di Kelas X SMAN 5 Pekanbaru. Jurnal Online Mahasiswa Fakultas Keguruan dan Ilmu Pendidikan Universitas Riau, 4(1), 1-10.

Wulansari, T., Putra, A., Rusliah, N., \& Habibi, M. (2019). Pengaruh Model Pembelajaran Berbasis Masalah pada Materi Statistika Terhadap Kemampuan Penalaran Statistik Siswa. AKSIOMA: Jurnal Matematika dan Pendidikan Matematika, 10(1), 35-47.

Zaini, H. (2008). Strategi Pembelajaran Aktif. Yogya-karta: Pustaka Insan Madani 